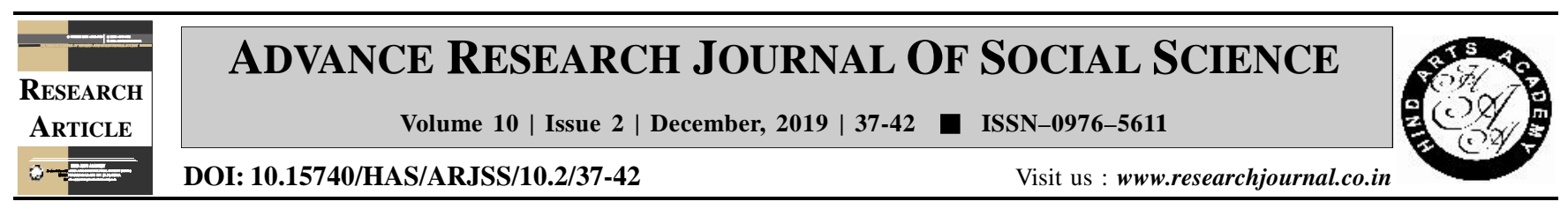

\title{
Infrastructural facilities for differently abled students in higher education
}

Asha Gohain*, Leena Das and Mira Kalita

Department of Family Resource Management and Consumer Science, College of Community Science, Assam Agricultural University, Jorhat (Assam) India

(Email : asha.gohain151@gmail.com)

\section{ARTICLE INFO :}

$\begin{array}{lll}\text { Received } & : & 27.10 .2019 \\ \text { Revised } & : & 01.11 .2019 \\ \text { Accepted } & : & 18.11 .2019\end{array}$

KEY WORDS :

Infrastructural facilities, Differently abled students, Higher education

HOW TO CITE THIS ARTICLE :

Gohain, Asha, Das, Leena and Kalita, Mira (2019). Infrastructural facilities for differently abled students in higher education. Adv. Res. J. Soc. Sci., 10 (2) : 37-42, DOI: 10.15740/HAS/ARJSS/ 10.2/37-42. Copyright@2019: Hind Agri -Horticultural Society

*Author for correspondence

\begin{abstract}
A study on different infrastructural facilities for differently abled students in higher education was carried out in Jorhat district of Assam. To ensure education of the differently able students it is important to make the environment accessible for them. To bring the students to the mainstream, we need more barrier-free environments in schools and colleges and public places too because higher education enhances employment participation and at the same time meets economic and social goals. The goal of barrier-free design is to provide an environment that supports independent functioning of individuals so that they can participate in all activities without assistance. To explore the. The students who are studying in different colleges in Jorhat area expressed that they face some difficulties with regard to infrastructural facilities like entrance gate with cattle bridge, no alternative entrance for differently abled students, lack of ramps, classroom at upper floor, slippery floor finishes and lack of accessible toilets which also hinder them in their education. Steps need to be taken to provide equal access to education to every category of disabled persons as an integral part of the education system. Lack of proper infrastructural facilities for differently abled students in institutions of higher education make it inconvenient to access the available facilities. Many students discontinue their study because of problems they face with regard to infrastructure. Convenient infrastructural facilities in institutions will help them acquiring higher education that leads to empowerment which, in turn, will lead to better employment opportunities.
\end{abstract}

